УАK 349.2:371.4

ББК $67.405 .1+74.200$

DOI 10.22394/1682-2358-2021-2-73-79

A.A. Ivanov, Candidate of Sciences (Law), Docent of the Labor Law Department, Saratov State Academy of Law

Yu.A. Kondrashov, Candidate of Sciences (Law), Docent of the Theory of State and Law Department, Saratov State Academy of Law

\section{IMPLEMENTING THE PRINCIPLE OF LEGALITY IN IMPROVING EDUCATIONAL ORGANIZATIONS TERRITORIES}

Issues of legality of using students', their legal representatives and teachers' labor on the territory of schools from the point of view of Russian and international legislation are considered. The article analyzes the issues related to involving students (and their parents) in the activities aimed at improving the territory and premises of an educational institutions from the point of view of the federal law "On Environmental Protection" and bylaws and instilling socially significant qualities in the younger generation.

Key words and word-combinations: subbotnik, Constitution of the Russian Federation, Labor Code of the Russian Federation, secondary school, legality.
А.А. ИВанов, кандидат юридических наук, доцент кафедри трудового прања Саратовской государственной юридической академии (email: artiom-depeche@yandex.ru)

Ю.А. Кондрашов, кандидат юридических наук, дочент кафедри теори государства и права Саратовской государственной юридической академии (email: yakondor@mail.ru)

\section{РЕААИЗАЦИЯ ПРИНЦИПА ЗАКОННОСТИ В МЕРОПРИЯТИЯХ ПО ОБААГОРАЖИВАНИЮ ТЕРРИТОРИЙ ОБРАЗОВАТЕ $\Lambda$ ЫНЫХ ОРГАНИЗАЦИЙ}

\footnotetext{
Аннотация. Рассматриваются вопросы ле-
} гальности применения труда учащихся, их родителей (законных представителей) и педагогов на территории школ с позиции российского и международного законодательства. Анализируются положения федеральных законов «Об образовании в Российской Федерации» и «Об охране окружающей среды», а также подзаконных актов, касающихся рассматриваемой проблемы.

Ключевые слова и словосочетания: субботник, Конституция РФ, Трудовой кодекс РФ, средняя общеобразовательная школа, законность

$\mathrm{O}$ сновополагающий принцип законности действует во всех сферах жизни общества и государства, распространяется и на действия органов власти разАичного уровня. В митературе существуют различ- 
ные подходы к пониманию законности. Так, В.А. Кулапов понимает под законностью правовой нормативный режим общественной жизни, который основан на системе требований по строгому и неуклонному соблюдению законодательства всеми государственными органами, должностными миџами, предприятиями, учреждениями и гражданами [1, с. 408]. Аругие исследователи рассматривают законность как основу нормальной жизнедеятельности общества и соџиально-политической системы [2]. Еще в начале нулевых годов Президент РФ В.В. Путин отмечал, что поА государством следует понимать не только конкретную территорию, но и конституционный порядок и Аисциплину [3]. Попытаемся исследовать реализаџию данного принџипа в сфере трудовых и образовательных отношений, связанную с поиском ответа на вопрос о степени эффективности использования неквалифиџированного труда участниками образовательных отношений на территориях учебных заведений.

Сегодня, несмотря на то, что почти тридџать мет назад Россия перешиа на рыночную экономику, такой атавизм советской эпохи, как «субботник», время от времени проводится в образовательных учреждениях. Нередки случаи привлечения учащихся, родителей и педагогов к массовым мероприятиям как в учебное, так и внеучебное время дмя уборки территорий и помешений. Аанные мероприятия проходят, как правияо, на Аобровольно-принуаительной основе, что запрещено Конституџией РФ [4], Трудовым кодексом РФ [5], Федеральным законом от 29 декабря 2012 г. № 273-Ф3 «Об образовании в Российской Федерации» [6] , а также нормами международного трудового права [7] .

Вместе с тем на основе анализа информации из различных источников (СМИ, Интернета) можно сделать вывод о том, что в сфере народного образования к принудительному труду привлекаются и педагоги, вынужденные без письменного согласия выполнять трудовую функџию, не преАусмотренную их трудовым Аоговором (в том числе в выходной день) при обещании работодателем предоставить компенсацию в виде отгула в дни каникул, и учащиеся, и их законные представители, вынужденные выходить на «субботник» в учебные и каникулярные дни. Следует отметить, что такая работа не предусмотрена образовательной программой. К примеру, в январе 2019 г. учителя школы № 95 Октябрьского района г. Саратова вышки на субботник в 20-градусный мороз собирать снег в мешки дмя мусора [8]. Еще печальнее, когда учащиеся получают травмы во время подобных мероприятий, что произошио в 2016 г. с учеником 2-го класса школы № 174 Жемезнодорожного района г. Самары. По результатам прокурорской проверки было выявлено, что ребенок пострадам из-за ненадлежащего исполнения своих домжностных обязанностей сотрудниками школы. Ответственность была возможена на руководителя образовательного учреждения [9]. В конџе апремя 2021 г. в г. Бузулуке в ходе проведения субботника молодой человек упал с дерева и был госпитализирован с травмой головы [10] .

74 Bulletin of the Volga Region Institute of Administration • 2021. Vol. 21. № 2 
Следовательно, проблема принудительного труда в сфере народного образования остается актуальной. Представляется целесообразным проанакизировать Аанную проблему в следующих аспектах:

- законность и правовое регулирование субботников в образовательных учреждениях с точки зрения их документального оформления и оплаты;

- поиск компромисса при проведении субботников и участия в них учащихся, их законных представителей и педагогов.

Исследование рассматриваемой проблемы через призму законности и соответствия законодательству основано на положениях Федерального закона «Об образовании в Российской Федераџии», где запрещено привлекать к субботникам учащихся и их законных представителей без их согласия. Следовательно, трудовая деятельность, связанная с благоустройством школьной территории и помещений, не может быть преАусмотрена образовательной программой. Российское трудовое законодательство также не содержит мегального понятия «субботник». Работодатель (руковоАитель образовательной организаџии) не может принудительно привлечь работников (педагогов) к участию в субботнике. Следовательно, понятие «субботник» в качестве юридического феномена с позиции норм ТК РФ (ст. 99) цогично отождествлять с законодательно закрепленной сверхурочной работой.

Это означает, что если администрация школы устраивает мероприятие, направленное на приведение в порядок помещений и школьной территории после окончания рабочего времени, субботник будет квамифиџирован как сверхурочная работа, выполняемая за предемами установленной для работника продомжительности рабочего времени. Таким образом, привлечь сотрудников к такой работе в соответствии с Аанной нормой можно мишь с их письменного согласия. ОАнако подчеркнем, что облагораживание школьной территории силами педагогических работников в принџипе недопустимо, ибо это противоречит основополагающим началам, цежащим в основе регулирования отношений, связанных с трудом, - выполнению своей трудовой функции, предусмотренной трудовым Аоговором. Запрещается использовать труд работника (педагога) не в соответствии с его трудовой функџией и вне условий трудового Аоговора. Аналогичный запрет преАусмотрен и дмя ситуации, если субботник проводится в выходной день (ст. 111 ТК РФ). Запрещается также применение к отказавшимся от участия в субботнике педагогам норм ст. 192 ТК РФ, предусматривающих меру Аисџиплинарной ответственности. Их отказ не явцяется основанием дия применения санкщий, в том числе связанных с Аишением соответствующих выплат. Это недопустимо, так как влечет правовые посмедствия для работодатемя: обращение педагога на законных основаниях в трудовую инспекцию (ст. 8 ТК РФ), как правило, заканчивается штрафом администрации образовательной организации в соответствии с ч. 1 ст. 5.27 КоАП РФ [11]. 
Таким образом, исходя из положений российского законодательства и межкуународного трудового права, посвященных работам, выполняемым Аля прямой пользы коммектива чменами данного коммектива, субботники в образовательных учреждениях могут проводиться исключительно на добровольной основе участников образовательных отношений.

Аокументальное оформление проведения субботника в соответствии с законодательством предполагает издание приказа [12, с. 94], который, по мнению специалистов в сферах бухгалтерии и хозяйственной работы в образовательных организациях, домжен содержать следующую информацию: дату и время проведения субботника; разработанный план конкретных мероприятий; данные об инвентаре и расходных материалах; ответственное мицо за проведение субботника; список задействованных в нем миц; указание бухгалтеру организации произвести оплату сверхурочной работы в соответствуюшем размере исходя из положений ТК РФ.

ОАнако представляется не всегда верным придерживаться практики применения оформления рассматриваемых отношений в приказной форме. Исходя из правовых и практических позиций, считаем правильным рекомендовать дмя документального оформления проведения субботника не форму приказа, а письменное согласие на добровольное участие в мероприятии по облагораживанию территории и помешений школы. По нашему мнению, приказ по своей природе применительно к Аанным отношениям противоречит принципам законности, добровольности и запрета принудительного труда. Аیя учащихся и их родителей (иных законных преАставителей) достаточно письменного согласия (несогласия). ТруА педагогов, привлеченных к мероприятию, следует оплатить в соответствии с правиками ТК РФ о сверхурочной работе или работе в выходной день, если субботник выпадает на выходные Ани. В соответствии со ст. 99 ТК РФ первые Ава часа должны быть оплачены в полуторном размере, а последующие Ава - в двойном. Если субботник проводится в выходной день, то оплата осуществляется в Авойном размере. ОАнако, так как субботник не является трудовой функщией педагогического состава и соответствующего обслуживающего персонала, то администрации следует закмючать с участвующими в субботнике педагогами гражАанское соглашение о возмезАном оказании услуг. В таком случае их труд руководителю придется оплачивать из своих мичных среАств.

Участие в субботнике в образовательном учреждении носит исключительно добровольный характер, что подтверждается положениями ст. 37 Конституџии РФ, ТК РФ, межАународных нормативно-правовых актов и Федерального закона от 29 декабря 2012 г. № 273-Ф3 «Об образовании в Российской Федерации». Вместе с тем к началу весны территория школы, как правицо, нуждается в уборке, и руководитель образовательной организации оказывается в сложной ситуации, чтобы навести порядок.

Привлечение учащихся, их родителей и педагогов к решению данной

76 Bulletin of the Volga Region Institute of Administration • 2021. Vol. 21. № 2 
задачи, а также планирование деятельности в этой сфере целесообразно вести в смедующих направлениях:

1) убеждение учеников в необходимости культурного и бережного отношения к окружающей среде;

2) привлечение законных представителей учащихся к общественно помезному труду с позиџии наделения ребенка соџиально значимыми качествами;

3) убеждение сотрудников и педагогов в необходимости участия в поАобных мероприятиях в процессе формирования корпоративной культуры.

Аанные способы не противоречат российскому законодательству. ИсхоАя из норм Федерального закона № 273-Ф3 «Об образовании в Российской Федерации» и трудового законодательства, ученики вправе самостоятельно выбирать участие в школьных мероприятиях, не предусмотренных учебным планом. Учащимся следует объяснить, что субботник - это мероприятие, от успеха которого зависят все участники образовательных отношений конкретной школы. При этом рекомендуется такие мероприятия наполнить играми, конкурсами, акциями на тему экологии, что, безусловно, будет способствовать привитию ученикам бережного отношения к окружающей среде и пониманию их кичной ответственности за последствия, наносимые окружающей среде своими действиями. Все это находится в контексте с положениями Федерального закона от 10 января 2002 г. № 7-Ф3 «Об охране окружающей среды» [13] и п. 2 раздела III Стратегии, утвержденной распоряжениями Правительства РФ от 29 мая 2015 г. № 996-p [14] .

Цемесообразно планировать субботник в качестве одного из направлений большого экологического мероприятия, проводяшегося в масштабах города (района) [12, с. 94]. Так, заслуживает внимания методическая разработка педагога-организатора Морозовского отдела детского творчества МБОУ АО «Аворец детского (юношеского) творчества детей Всеволжского района Аенинградской области, представцяющая собой пошаговый сџенарий проведения экологического квеста [13]. Џелью данного мероприятия явцяется сплочение детского комектива через игру, создание положительной атмосферы [14]. Задачами для достижения указанной автором

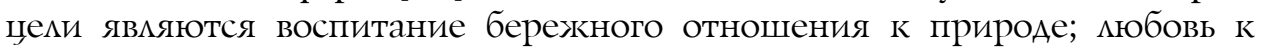
родному краю; воспитание соџиальной ответственности учащихся за чистоту в городе; воспитание интереса к здоровому образу жизни; повышение готовности детей к участию в экологически ориентированной деятельности; развитие умения работы в команде, стремления к победе, творческих, умственных и физических навыков [15, с. 72-73] .

Привлечение родителей (законных представителей) к подобным мероприятиям должно осуществцяться на основе соображений, связанных с правильным примером родителя своему ребенку, общей деятельностью на общественное благо [16, с. 91] . 
Привлечение педагогов к исполнению трудовых обязанностей, не преАусмотренных трудовым договором, как уже подчеркивалось, не предусмотрено трудовым законодательством, поэтому в случае отказа нормы ТК РФ о Аисциплинарной ответственности к ним неприменимы. САожность состоит в том, что участие в субботниках не входит в должностные обязанности пеАагога, поэтому не явмяется критерием стимулирующих выплат, которые входят в состав зарплаты и выплачиваются за исполнение должностных обязанностей по занимаемой домжности (ч. 1 ст. 129 ТК РФ). МежАу тем мичное трудовое участие руководителя в мероприятии будет способствовать развитию в учащихся соџиально значимых качеств, разрушит стереотип о субботниках как о пережитке советского прошиого.

Таким образом, можно сделать следующие выводы:

участие в субботнике явмяется искмючительно добровольным, так как в противном случае оно будет квалифицироваться как принудительный труА;

Аля оформления субботника с привлечением учащихся следует использовать форму письменного согласия (несогласия) их законных преАставителей;

при участии педагогов и обслуживающего персонала в субботнике цемесообразно применять правила ст. 99 ТК РФ об оплате сверхурочной работы или работы в выходной день в соответствии с конституционными положениями ст. 37 о возмездной оплате труда и заключать письменные гражданские соглашения о возмездном оказании услуг.

Исследователи придерживаются единой точки зрения о том, что будь это образовательные учреждения или публично-правовые образования, - все они обязаны соблюдать закон и установленные нормы [17-19]. В противном случае использование властных полномочий работодателей дмя обхода действующего законодательства, запрещающего принудительный труд, особенно когда они не привлекаются к ответственности, ведет к правовому нигилизму и, как следствие, обесцениванию принџипа законности. Подобная ситуаџия обусловлена низким уровнем правосознания и домжностных миџ муниципальных органов власти, задействованных в проведении политики в сфере образования, и непосредственных участников образовательных отношений (пеАагогов, родителей, учащихся), которые принимают такую экспцуатацию. Необходимо поднять уровень правового воспитания и правовой культуры как государственных и муниципальных должностных Аиџ, в том числе руководителей муниципальных образовательных учреждений), так и населения, которое по незнанию привлекается к добровольно-принудительному труду [20], что может быть достигнуто путем повышения соџиально-правовой активности граждан.

\section{Библиографический список}

1. Кулапов В.Л. Теория государства и права: учебник. Саратов, 2019. 
2. Кожевников С.Н. Законность: основные грани // Пробелы в российском законодательстве. 2016. № 2. С. 40-42.

3. Путин В.В. Власть должна быть работающей // Российская газета. 2000. 19 мая.

4. Конституция Российской Федерации (принята всенародным голосованием 12 нояб. 1993 г., с изм., одобренными в ходе общероссийского голосования 1 июля 2020 г.) // Российская газета. 2020. 4 июля.

5. Трудовой кодекс Российской Федерации от 30 дек. 2001 г. № 197-Ф3 (с изм. от 9 марта 2021 г. № 34-Ф3) // С3 РФ. 2002. № 1 (ч. І). Ст. 3.

6. Об образовании в Российской Федерации: Федер. закон от 29 дек. 2012 г. № 273-Ф3 (с изм. от 17 февр. 2021 г. № 10-ФЗ) // СЗ РФ. 2012. № 53 (ч. 1). Ст. 7598.

7. Конвенция № 29 Международной организации труда относительно принудительного или обязательного труда (принята в г. Женеве 28 июня 1930 г. на 14-й сессии Генеральной конференции МОТ) (с изм. от 11 июня 2014 г.) // Ведомости ВС СССР. 1956. № 13. Ст. 279.

8. Скандал в Саратове: учителей школы заставили выйти на субботник в 20-градусный мороз. URL: http://vesti.ru/doc.html?id=3109844

9. В Самаре на субботнике пострадал второклассник и попал в больницу. URL: http:// progorodsamara.ru/news/view/184247

10. В Бузулуке субботник закончился ЧП. URL: http:/orenday.ru/news/ 250421013800?utm_source=yxnews\&utm_medium=desktop

11. Кодекс Российской Федерации об административных правонарушениях от 30 дек. 2001 г. № 195-Ф3 (с изм. от 9 марта 2021 г. № 38-Ф3) // СЗ РФ. 2002. № 1 (ч. 1). Ст. 1.

12. Яриева В. Как организовать субботник, на который придут все: Образец приказа // Справочник руководителя образовательного учреждения. 2019. № 4. С. 92-96.

13. Об охране окружающей среды: Федер. закон от 10 июня 2002 г. № 7-Ф3 (с изм. от 9 марта 2021 г. № 39-Ф3) // СЗ РФ. 2002. № 2. Ст. 133.

14. Об утверждении Стратегии развития воспитания в Российской Федерации на период до 2025 года: распоряжение Правительства РФ от 29 мая 2015 г. № 996-р // СЗ РФ. 2015. № 23. Ст. 3357.

15. Запорожеи M.C. В поисках клада: Игровой субботник для детей среднего школьного возраста // Открытый урок: методики, сценарии и примеры. 2018. № 7. С. 72-75.

16. Маслова E. Как организовать субботник, чтобы родители на него пришли // Справочник руководителя дошкольного учреждения. 2017. № 9. С. 88-91.

17. Колпакова E.E. К вопросу о месте принципа законности в системе принципов юридической ответственности публично-правовых образований // Вестник Волжского университета им. В.Н. Татищева. 2013. № 4 (79). С. 84-94.

18. Оганесян А.Л. Законность - основополагающий принцип взаимодействия органов местного самоуправления с предприятиями, организациями и учреждениями на территории муниципального образования // Бизнес в законе. 2008. № 1. С. 43-45.

19. Колпакова E.E. Влияние принципа законности на процесс реализации юридической ответственности публично-правовых образований // Вестник Самарского госуниверситета. 2014. № 2 (112). С. 115-121.

20. Винницкий И.Е. Законность и правовое воспитание властных субъектов // Право и образование. 2015. № 5. С. 111-120. 